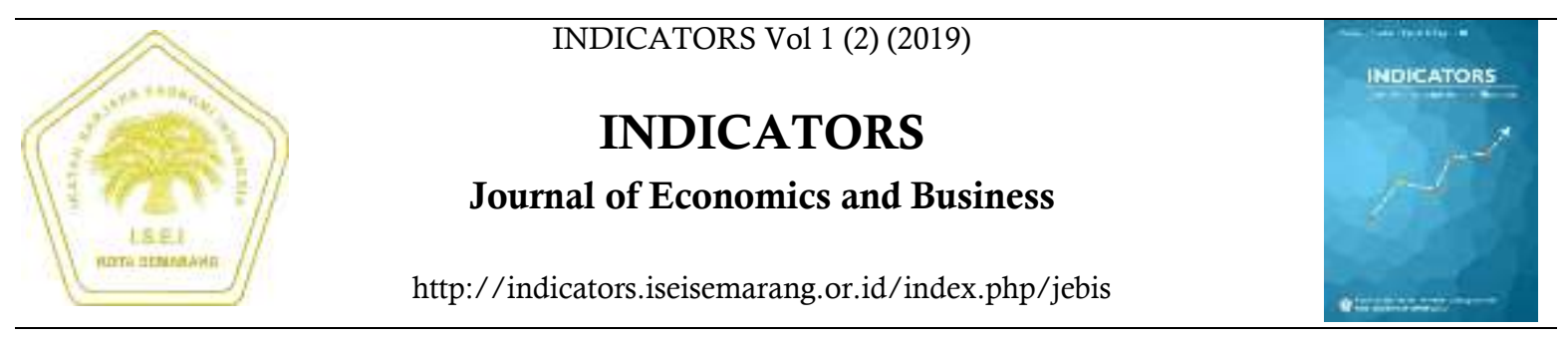

\title{
PENGARUH SPESIALISASI INDUSTRI AUDITOR, REPUTASI AUDITOR, DAN AUDIT TENURE TERHADAP AUDIT REPORT LAG
}

\author{
Dyah Puspa Arumningtyas, Adi Firman Ramadhan ${ }^{\bowtie}$
}

Departemen Akuntansi, Fakultas Ekonomika dan Bisnis, Universitas Diponegoro

\begin{tabular}{|c|c|}
\hline Info Artikel & Abstract \\
\hline Sejarah Artikel: & This study aims to empirically examine the relationship between industry auditor specialization, auditor \\
\hline Diterima Mei 2019 & reputation, and audit tenure, to audit report lag in manufacturing companies listed on the Indonesia Stock \\
\hline Disetujui Agustus 2019 & Exchange in 2015-2017. The population in this study are manufacturing companies listed on the Indonesia \\
\hline Dipublikasikan & Stock Exchange in 2015-2017. The research sample consisted of 67 companies listed on the Indonesia Stock \\
\hline November 2019 & $\begin{array}{l}\text { Exchange for the period 2015-2017. The data used in this study are secondary data and sample selection using } \\
\text { purposive sampling method. The analysis model uses multiple linear regression analysis. The results of this study }\end{array}$ \\
\hline & $\begin{array}{l}\text { indicate that auditor industry specialization has a negative effect on audit report lag, auditor reputation has no } \\
\text { effect on audit report lag, and audit tenure has a negative effect on audit report lag. }\end{array}$ \\
\hline
\end{tabular}

industry specialization,

auditor reputation, audit

tenure

\footnotetext{
${ }^{\square}$ Alamat korespondensi:

J1. Prof. Soedharto SH Tembalang, Semarang 50239

Phone: +622476486851

E-mail: (afran.ramadhan@gmail.com)
} 


\section{PENDAHULUAN}

Sumber terpercaya dan informasi akuntansi yang tersedia untuk pihak eksternal adalah laporan keuangan yang sudah diaudit (Alkhatib dan Marji, 2012) Menurut Financial Accounting Standard Board (FASB) dalam Statement of Financial Accounting Concepts (SFAC) No 2 laporan keuangan harus relevance dan reliability. Informasi yang relevan bermanfaat bagi investor, kreditor, dan pemakai laporan keuangan lainnya untuk mengevaluasi peristiwa masa lalu, masa sekarang, dan masa depan (predictive value), lalu memperbaiki harapan yang dibuat sebelumnya (feedback value), serta informasi harus tersedia tepat waktu bagi pengambil keputusan sebelum mereka kehilangan kesempatan/kemampuan untuk mempengaruhi keputusan yang diambil (timeliness) (Ghozali dan Chariri 2014).

Perusahaan yang terdaftar di Bursa Efek Indonesia (BEI) wajib menyampaikan laporan keuangan secara tepat waktu. Berdasarkan Peraturan Otoritas Jasa Keuangan Nomor 29/POJK.04/2016 tentang Laporan Tahunan Emiten atau Perusahaan Publik, Emiten atau Perusahaan Publik wajib menyampaikan Laporan Tahunan kepada OJK yang disertai laporan keuangan tahunan auditan, dengan batas akhir maksimal yaitu akhir bulan ke 4 (empat) pada periode sesudah tutup tahun buku entitas.

Ketepatan waktu penyampaian laporan keuangan ke publik menjadi tanda dari perusahaan yang memperlihatkan terdapat informasi bermanfaat bagi investor dalam menentukan keputusan bisnis. Walaupun demikian, menurut data dari Bursa Efek Indonesia masih terdapat emiten yang menyampaikan laporan keuangan tidak tepat waktu. Pada tahun 2017 terdapat 10 emiten terlambat menyampaikan laporan keuangan per 31 Desember 2016. Lalu pada tahun 2016 terdapat 17 emiten terlambat menyampaikan laporan keuangan per 31 Desember 2015. Selanjutnya pada tahun 2015 terdapat 52 emiten yang terlambat menyampaikan laporan keuangan per 31 Desember 2014.

Adanya perusahaan yang terlambat menyampaikan laporan keuangan, merupakan bukti bahwa ketepatan waktu masih menjadi hambatan bagi perusahaan di Indonesia. Keterlambatan penyampaian laporan keuangan perusahaan tersebut mengindikasikan audit report lag melebihi batas yang telah ditetapkan oleh regulator.

Audit report lag adalah jumlah hari penyelesaian audit yang dihitung dari tanggal akhir tahun fiskal perusahaan sampai auditor menandatangani laporan audit (Rusmin dan Evans, 2017). Audit report lag dapat dipengaruhi oleh beberapa variabel, diantaranya adalah spesialisasi industri auditor, reputasi auditor, dan audit tenure.

Penelitian ini melihat fungsi spesialisasi industri auditor, reputasi auditor, serta audit tenure dalam mempengaruhi audit report lag. Spesialisai industri auditor adalah keahlian yang dimiliki oleh auditor mengenai suatu bidang industri tertentu. Spesialisasi industri auditor diharapkan dapat memberikan jasa audit dan kredibbilitas yang unggul (Solomon, Shields, dan Whittington, 1999). Dengan demikian, spesialisasi industri auditor cenderung mampu untuk menyelesaikan pekerjaan audit lebih cepat dibandingkan dengan non spesialisasi industri auditor.

Selain spesialisasi industri auditor, penelitian ini menyelidiki hubungan antara reputasi auditor yang diproksikan oleh perusahaan audit Big 4 dalam audit report lag. Perusahaan audit Big 4 memiliki lebih banyak sumber daya (Palmrose, 1986b), lebih berisiko dalam hal reputasi (Francis dan Wilson, 1988), dan mempunyai staf berkualitas tinggi (Chan et al., 1993b) oleh karena itu dapat memberikan kualitas audit yang tinggi. Dengan kata lain, auditor Big 4 diharapkan dapat memberikan jasa audit lebih cepat yang mengarah ke audit report lag yang lebih pendek.

Demikian halnya dengan audit tenure dapat memberikan pengaruh terhadap ketepatan waktu laporan audit. Audit tenure adalah lamanya hubungan kerja antara auditor dengan klien dalam memeriksa laporan keuangan. Lee et al. (2009) menyatakan audit tenure yang panjang akan menghasilkan audit report lag yang pendek, karena auditor lebih mengerti operasi, risiko bisnis, serta sistem akuntansi perusahaan klien. 


\section{KERANGKA PEMIKIRAN TEORITIS DAN PERUMUSAN HIPOTESIS}

Pengaruh spesialisasi industri auditor, reputasi auditor, dan audi tenure terhadap audit report lag didasari oleh teori agensi. Menurut Jensen dan Meckling (1976) teori keagenan merupakan perjanjian antara satu orang atau lebih (prinsipal) terhadap pihak lain (agen) untuk melakukan jasa dengan mengatasnamakan prinsipal, serta memberi otoritas kepada agen untuk mengambil keputusan. Dalam teori agensi terdapat asimetri informasi antara agen (menajer) dan prinsipal (pemegang saham). Asimetri informasi muncul saat manajer memiliki akses informasi atas prospek perusahaan yang tidak dimiliki oleh pemegang saham dan stakeholder lainnya (Anggraeni, 2011).

Menurut Jensen dan Meckling (1976) asimetri informasi dapat memicu agency problem bagi perusahaan, yaitu:

1. Moral Hazard adalah persoalan karena agen berperilaku tidak jujur sehingga melanggar kesepakatan dalam kontrak kerja.

2. Adverse Selection adalah kondisi dimana prinsipal tidak mengetahui apakah keputusan yang diambil agen didasarkan atas informasi, atau terjadi sebagai sebuah kelalaian tugas.

Agency problem tersebut akan menimbulkan

biaya keagenan. Biaya keagenan terbagi menjadi 3, yaitu:

1. Biaya pemantauan adalah biaya yang dikeluarkan oleh prinsipal untuk mengawasi perilaku agen.

2. Biaya ikatan adalah biaya yang dikeluarkan oleh agen untuk menjamin bahwa agen telah melakukan hal yang sesuai dengan kepentingan prinsipal.

3. Kerugian residual adalah pengorbanan akibat terdapat perbedaan antara keputusan prinsipal dengan keputusan agen.

Menurut Adams (1994) untuk mengatasi agency problem maka diperlukan pihak ketiga yaitu auditor eksternal untuk meminimalisir terjadinya pelanggaran yang dilakukan agen terhadap kontrak kerja. Maka dari itu, prinsipal akan mengeluarkan biaya pemantauan untuk pemeriksaan laporan keuangan kepada auditor eksternal.

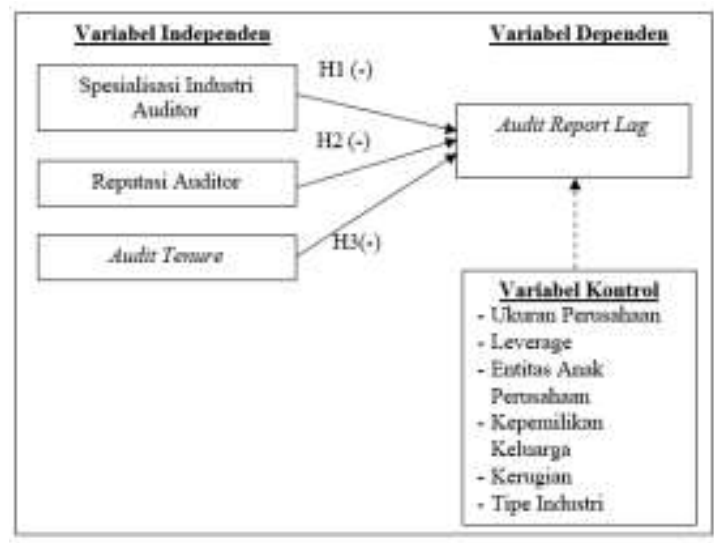

\section{Pengaruh Spesialisasi Industri Auditor terhadap Audit Report Lag}

Menurut Michael dan Rohman (2017) dalam teori agensi untuk menengahi kepentingan manajer selaku agen dan pemilik selaku prinsipal diperlukan pihak ketiga yaitu auditor independen. Maka dari itu, dibutuhkan auditor yang memiliki pengalaman dan pengetahuan mengenai perusahaan klien. Pengetahuan khusus mengenai suatu industri yang dimiliki oleh spesialisasi industri auditor menjadi hal penting yang perlu dipertimbangkan perusahaan dalam memilih auditor independen.

Penggunaan spesialisasi industri auditor dapat meningkatkan kualitas audit dan kualitas laporan keuangan (Dopuch dan Simunic, 1982). Spesialisasi industri auditor membutuhkan waktu yang lebih singkat untuk menguasai sistem pelaporan keuangan klien dan memecahkan masalah akuntansi yang rumit dibandingkan dengan auditor non-spesialis (Habib dan Bhuiyan, 2011). Dengan demikian, spesialisasi industri auditor diharapkan dapat menyelesaikan pekerjaan audit lebih cepat.

Berdasarkan uraian diatas, maka hipotesis yang diajukan yaitu:

H1 : Spesialisasi industri auditor berpengaruh negatif terhadap audit report lag

\section{Pengaruh Reputasi Auditor terhadap Audit Report Lag}

Menurut Adams (1994) untuk menengahi kepentingan antara pihak agen (manajer) dan prinsipal (pemilik), keduanya akan dikenakan biaya kontrak yang tidak merugikan satu sama lain. Untuk meminimalkan risiko kelalaian yang dilakukan oleh agen terhadap kontrak kerja, 
maka prinsipal akan mengeluarkan biaya pemantauan untuk pemeriksaan laporan keuangan oleh audit eksternal.

Kualitas kerja audit bervariasi di antara perusahaan audit (DeAngelo, 1981; Francis et al., 1999). Perusahaan audit Big 4 dapat memberikan kualitas audit yang lebih tinggi daripada non-Big 4 (DeAngelo, 1981; Watts dan Zimmerman, 1986; Becker et al., 1998; Caneghem, 2004). Menurut Caneghem (dalam Rusmin dan Evans, 2017), Big 4 dapat memberikan kualitas audit yang baik karena mereka memiliki: (1) staf lebih berkualitas, (2) jumlah klien lebih banyak, (3) lebih banyak kesempatan untuk menggunakan sumber daya untuk mengaudit (rekrutmen, pelatihan dan teknologi), dan (4) lebih beresiko, misalnya, penghentian klien dan hilangnya reputasi.

Menurut Afify (2009) perusahaan audit Big 4 cenderung dapat menuntaskan pekerjaan audit lebih cepat untuk mempertahankan reputasi mereka. Perusahaan audit Big 4 memiliki lebih banyak sumber daya (Palmrose, 1986a), kualitas yang lebih baik serta staf yang lebih terlatih (Chan et al., 1993a), teknologi audit (William dan Dirsmith, 1988), dan mampu melakukan audit lebih efisien serta tepat waktu (Gilling, 1977; Hassan, 2016). Demikian juga, perusahaan audit afiliasi internasional dapat menyediakan layanan yang lebih cepat untuk meningkatkan pangsa pasar audit mereka (Leventis et al., 2005).

Berdasarkan uraian diatas, maka hipotesis yang diajukan yaitu:

H2: Reputasi auditor berpengaruh negatif terhadap audit report lag.

\section{Pengaruh Audit Tenure terhadap Audit Report Lag}

Menurut Michael dan Rohman (2017) teori agensi menjelaskan hubungan antara prinsipal (pemilik) dengan agen (manajer) yang memiliki tujuan yang berbeda, namun saling membutuhkan. Lamanya penyampaian laporan keuangan dapat menimbulkan asimetri informasi. Oleh karena itu, auditor memiliki peran penting untuk memeriksa dan mengawasi kinerja manajemen agar tidak menyimpang dari tujuan perusahaan.
Penelitian Dao dan Pham (2014) menghasilkan bukti bahwa audit tenure yang pendek akan menghasilkan audit report lag yang lebih lama. Auditor tidak mempunyai pengetahuan yang cukup tentang klien mereka dan industri pada tahun awal hubungan auditor dan klien (Carcello dan Nagy, 2004). Penelitian sebelumnya menemukan bahwa audit report lag lebih pendek ketika audit tenure perusahaan panjang (Lee et al., 2009), audit tenure perusahaan yang panjang dapat menyebabkan kurangnya objektivitas auditor, yang mungkin menghasilkan kualitas audit yang lebih rendah (Carcello dan Nagy, 2004).

Berdasarkan uraian diatas, maka hipotesis yang diajukan yaitu:

\section{H3: Audit tenure berpengaruh negatif terhadap audit report lag.}

\section{METODE PENELITIAN}

\section{Variabel Penelitian}

Variabel dependen dalam penelitian ini adalah audit report lag. Selanjutnya variabel independen dalam penelitian ini adalah spesialisasi industri auditor, reputasi auditor, dan audit tenure. Lalu variabel kontrol yang digunakan yaitu ukuran perusahaan, leverage, entitas anak perusahaan, kepemilikan keluarga, kerugian, dan tipe industri.

\section{Audit Report Lag}

Audit report lag pada penelitian ini diukur berdasarkan jumlah hari dari akhir tahun fiskal sampai dengan auditor menandatangani laporan audit.

\section{Spesialisasi Industri Auditor}

Spesialisasi industri auditor sulit diamati secara langsung dan oleh karena itu harus menggunakan proksi untuk estimasi yang relevan (Rusmin dan Evans, 2017). Penelitian ini mengikuti penelitian yang dilakukan oleh Krishnan (2003) menggunakan total aset sebagai dasar untuk memperkirakan pangsa pasar industri auditor. Pangsa pasar merupakan hasil bagi dari total aset klien yang diaudit oleh perusahaan audit pada sektor industri tertentu 
terhadap total aset klien yang diaudit oleh semua perusahaan audit pada sektor industri tersebut. Cara mengukur spesialisasi industri auditor dapat dirumuskan sebagai berikut :

$$
M S_{i k}=\frac{\sum_{j=1}^{j i k} \text { Total Aset }_{i j k}}{\sum_{k=1}^{K} \sum_{j=1}^{j i k} \text { Total Aset }_{j k}}
$$

Keterangan :

i :

indikator perusahaan audit

$\mathrm{j}: \quad$ indikator perusahaan klien

$\mathrm{k}$ : $\quad$ indikator indusri klien

$\mathrm{I}_{k}: \quad$ jumlah perusahaan audit pada

industri $\mathrm{K}$

$\mathrm{J}_{i k}$ : jumlah klien yang diaudit oleh perusahaan audit I pada industri $\mathrm{k}$

Total Aset ${ }_{i j k}$ : total asset klien $\mathrm{j}$ yang diaudit oleh auditor I pada industri $\mathrm{k}$

Spesialisasi industri auditor ditentukan berdasarkan perusahaan audit yamg memiliki pangsa pasar minimal 15\% dalam sektor industri tertentu (Krishnan, 2003). Variabel ini diukur dengan menggunakan variabel dummy berdasarkan kemungkinan bahwa perusahaan sampel menggunakan auditor spesialis industri atau tidak. Apabila perusahaan tersebut menggunakan auditor spesialis industri maka mendapat angka 1 , jika tidak maka 0.

\section{Reputasi Auditor}

Reputasi auditor dalam penelitian ini diproksikan oleh perusahaan audit Big 4 yang diukur dengan menggunakan variabel dummy. Apabila perusahaan tersebut menggunakan auditor Big 4 pada tahun fiskal maka mendapat angka 1, jika tidak maka 0. Perusahaan audit Big 4 diharapkan dapat menyelesaikan pekerjaan audit lebih cepat daripada rekan non-Big 4 dan juga dapat menyediakan layanan yang lebih cepat dan efisien yang mengarah ke audit report lag yang lebih pendek.

\section{Audit Tenure}

Dalam POJK Nomor 13 Tahun 2017 tentang Penggunaan Jasa Akuntan Publik dan Kantor Akuntan Publik dalam Kegiatan Jasa Keuangan, diatur bahwa institusi jasa keuangan wajib membatasi penggunaan jasa audit dari AP paling lama 3 (tiga) tahun buku berturut-turut. Audit tenure pada penelitian ini diukur dengan cara menghitung jumlah tahun auditor melakukan perikatan kerja dengan perusahaan klien yang sama.

\section{Ukuran Perusahaan}

Ukuran perusahaan pada penelitian ini diukur menggunakan total aset yang dimiliki oleh perusahaan. Total asset perusahaan diukur menggunakan logaritma natural atas total aset perusahaan.

\section{Leverage}

Mengacu pada penelitian yang dilakukan oleh Rusmin dan Evans (2017), leverage diukur berdasarkan rasio total utang perusahaan terhadap total ekuitas perusahan.

$$
\text { Leverage }=\frac{\text { Total Utang }}{\text { Total Ekuitas }}
$$

\section{Entitas Anak Perusahaan}

Entitas anak perusahaan diukur dengan cara menghitung jumlah anak perusahaan yang dimiliki. Informasi mengenai entitas anak perusahaan diperoleh melalui CALK pada laporan tahunan.

\section{Kepemilikan Keluarga}

Menurut Valentino (2017), Perusahaan dikategorikan sebagai perusahaan milik keluarga apabila terdapat anggota keluarga menempati posisi Board of Director atau manajerial; atau kepemilikan sahamnya minimal $10 \%$. Pengukuran tersebut diselidiki dengan ketentuan jika dalam pemegang saham perusahaan terdapat nama marga yang sama, bisa dikategorikan 
sebagai kepemilikan keluarga, selain itu dilakukan penelusuran melalui website perusahaan dan juga laporan tahunan perusahaan pada bagian catatan atas laporan keuangan. Pengukuran variabel kepemilikan keluarga menggunakan variabel dummy. Apabila perusahaan dimiliki oleh keluarga maka mendapat angka 1 , jika tidak maka 0 .

\section{Kerugian}

Kerugian dalam penelitian ini diukur dengan menggunakan variabel dummy. Apabila perusahaan melaporkan adanya kerugian pada tahun fiskal maka mendapat angka 1, jika tidak maka 0 .

\section{Tipe Industri}

Tipe industri dibagi menjadi dua bagian yaitu high profile industry yang terdiri dari pertambangan, industri dasar dan kimia, dan aneka industri. Lalu bagian kedua adalah low profile industy yang tidak termasuk ke dalam klasifikasi high profile industry. Variabel kontrol tipe industri diukur menggunakan variabel dummy. 1 jika perusahaan diklasifikasikan sebagai high profile industry, dan 0 jika perusahaan diklasifikasikan sebagai low profile industy.

\section{Populasi dan Sampel}

Populasi dalam penelitian ini adalah perusahaan manufaktur yang terdaftar di Bursa Efek Indonesia pada tahun 2015-2017. Penentuan sampel dalam penelitian ini menggunakan metode purposive sampling, yaitu memilih sampel dari populasi berdasarkan kriteria tertentu. Kriteria tersebut yaitu:

1. Perusahaan manufaktur yang terdaftar di Bursa Efek Indonesia dan mempublikasikan dengan lengkap laporan keuangan dan laporan audit pada tahun 2015 hingga 2017,

2. Perusahaan manufaktur yang menggunakan mata uang Rupiah dalam laporan keuangan.
3. Memiliki data yang dibutuhkan dalam variabel yang ada di penelitian ini.

\section{Metode Analisis}

Penelitian ini menggunakan analisis regresi linear berganda untuk menguji hipotesis. Persamaan regresi dari penelitian ini dapat dilihat sebagai berikut:

ARLi $=a_{i}+\gamma_{i 1}$ Spesialis $_{i}+\gamma_{i 2}$ Reputasi Auditor $_{i}+$ $\gamma_{\mathrm{i} 3}$ Audit Tenure $_{\mathrm{i}}+\alpha_{\mathrm{i} 1}$ Ukuran Perusahaan $_{\mathrm{i}}+\alpha_{\mathrm{i} 2}$ Leverage $_{i}+\alpha_{i 3}$ Entitas $_{\text {Anak }_{i}}+\alpha_{i 4}$ Keluarga $_{i}, \alpha_{i 5}$ Kerugian $_{\mathrm{i}}+\alpha_{\mathrm{i} 6}$ Industri $_{\mathrm{i}}+\varepsilon_{\mathrm{i}}$

\section{Keterangan :}

ARL : Jumlah hari dari akhir tahun keuangan hingga saat auditor menandatangani laporan audit

\section{$a_{i}: \quad$ Konstanta}

Spesialis: $\quad$ Varibel dummy, 1 jika auditor termasuk dalam spesialisasi industri, dan 0 sebaliknya

Reputasi Auditor : $\quad$ Varibel dummy, 1 jika KAP berafiliasi dengan Big 4, dan 0 sebaliknya

Audit Tenure ${ }_{\mathrm{i}}$ : Lamanya tahun perikatan auditor dengan klien

Ukuran Perusahaan ${ }_{\mathrm{i}}$ : Logaritma natural dari total aset perusahaan

Leverage $_{\mathrm{i}}$ : Rasio atas total utang perusahaan klien dibagi total ekuitas perusahaan klien

Entitas Anak k $_{i} \quad$ Jumlah entitas anak yang dimiliki oleh perusahaan klien

Keluarga $_{\mathrm{i}}$ : Variabel dummy, 1 jika perusahaan klien dimiliki oleh keluarga, dan 0 sebaliknya

Kerugian $_{\mathrm{i}}$ : Varibel dummy, 1 jika perusahaan klien melaporkan adanya kerugian pada tahun fiskal, dan 0 sebaliknya

Industri : $\quad$ Varibel dummy, 1 jika perusahaan klien termasuk dalam klasifikasi high 
profile industry (pertambangan, industri dasar \& kimia, dan aneka insutri), dan 0 sebaliknya.

\section{HASIL DAN PEMBAHASAN}

\section{Deskripsi Sampel Penelitian}

Pada tahun 2015-2017 tercatat ada 471 perusahaan manufaktur yang melaporkan laporan tahunan dan laporan keuangan pada website BEI. Dari 471 perusahaan tersebut terdapat 6 perusahaan mengalami delisting, 90 perusahaan tidak menggunakan satuan mata uang rupiah dalam melaporkan laporan keuangan dan laporan tahunan, 171 perusahaan memiliki data yang tidak lengkap untuk penelitian, lalu terdapat 19 data outlier. Total pengamatan dari penelitian ini berjumlah 185 perusahaan.

Tabel 1

Sampel Penelitian

\begin{tabular}{clc}
\hline No & \multicolumn{1}{c}{ Keterangan } & Jumlah Perusahaan \\
\hline 1 & $\begin{array}{l}\text { Perusahaan manufaktur yang terdaftar di BEI dan melaporkan laporan } \\
\text { tahunan dan laporan keuangannya pada tahun 2015-2017 }\end{array}$ & 471 \\
2 & $\begin{array}{l}\text { Perusahaan yang mengalami delisting } \\
3\end{array}$ & $(6)$ \\
& $\begin{array}{l}\text { Perusahaan yang tidak menggunakan satuan mata uang rupiah dalam } \\
\text { melaporkan laporan keuangan dan tahunan }\end{array}$ & $(90)$ \\
4 & $\begin{array}{l}\text { Perusahaan yang tidak mencakup data lengkap terkait dengan variabel } \\
\text { penelitian }\end{array}$ & $(171)$ \\
5 & Jumlah & 204 \\
6 & Outlier & 19 \\
$\mathbf{7}$ & Total Pengamatan & $\mathbf{1 8 5}$ \\
\hline
\end{tabular}

Sumber : Data sekunder yang diolah, 2019

Tabel 2

Statistik Deskriptif

\begin{tabular}{lccccc}
\hline & $\mathrm{N}$ & Min & Max & Mean & Std. Deviation \\
\hline Audi Report Lag & 185 & 46,00 & 99,00 & 77,729 & 10,992 \\
Audit Tenure & 185 & 1,00 & 3,00 & 1,6216 & 0,77148 \\
Ukuran Perusahaan & 185 & 25,18 & 33,32 & 28,4379 & 1,76679 \\
Leverage & 185 & $-5,02$ & 5,39 & 1,0357 & 1,20606 \\
Entitas Anak & 185 & 0,00 & 110,0 & 9,6000 & 18,76462
\end{tabular}

Sumber : Data sekunder yang diolah, 2019

Berdasarkan tabel 2 diperoleh informasi informasi yaitu total pegamatan yang digunakan dalam penelitian berjumlah 185 untuk setiap variabel penelitian. Variabel audit report lag merupakan variabel dependen yang memiliki nilai minimum 46 hari dan nilai maksimum 99 hari. Audit report lag mempunyai nilai rata-rata (mean) 78 hari, hal ini memiliki arti bahwa ratarata perusahaan sampel memiliki jangka waktu penyelesaian audit selama 78 hari.

Variabel independen dalam penelitian ini adalah spesialisasi industri auditor, reputasi auditor, dan audit tenure. Audit tenure diukur dengan cara menghitung jumlah tahun auditor melakukan perikatan kerja dengan perusahaan klien yang sama. Pada tabel 2 variabel audit tenure memiliki nilai minimum 1 dan nilai maksimum 3 , serta rata-rata 1,6216 , hasil ini membukrikan bahwa sebagian besar perikatan audit di Indonesia adalah sekitar 1 sampai 2 tahun.

Variabel kontrol dalam penelitian ini terdiri dari ukuran perusahaan, leverage, entitas anak perusahaan, kepemilikan keluarga, kerugian, dan tipe industri. Variabel ukuran perusahaan dalam penelitian ini diukur menggunakan total aset yang dimiliki oleh perusahaan klien. Total asset perusahaan ditranformasi menggunakan logaritma natural. Pada tabel 2 ukuran perusahaan memiliki nilai minimum 25,18 dan nilai maksimum 33,32 dengan rata-rata 28,4379 , serta deviasi standar sebesar 1,76679. 
Variabel leverage diukur dari rasio total hutang terhadap total ekuitas. Leverage dalam penelitian ini menunjukkan nilai minimum $-5,02$ dan nilai maksimum 5,39. Rata-rata leverage sebesar 1,0357 dengan deviasi standar sebesar 1,20606. Variabel entitas anak perusahaan pada penelitian ini diukur dengan cara menghitung jumlah anak

Tabel 3

Statistik Distribusi Frekuensi Variabel Spesialisasi Industri Auditor

\begin{tabular}{lll}
\hline & Frequency & Percent \\
\hline Non Spesialis (0) & 122 & 65,9 \\
Spesialis (1) & 63 & 34,1 \\
Total & 185 & 100 \\
\hline
\end{tabular}

Sumber : Data sekunder yang diolah, 2019

Berdasarkan tabel 3 diperoleh informasi terdapat 122 sampel perusahaan yang menjadi klien nonspesialis atau sebanyak $65,9 \%$ dan terdapat 63

Tabel 4

Statistik Distribusi Frekuensi Reputasi Auditor

\begin{tabular}{lll}
\hline & Frequency & Percent \\
\hline Non Big 4(0) & 109 & 58,9 \\
Big 4 (1) & 76 & 41,1 \\
Total & 185 & 100 \\
\hline
\end{tabular}

Sumber : Data sekunder yang diolah, 2019

Berdasarkan tabel 4 dapat diketahui terdapat 109 sampel perusahaan yang tidak menggunakan jasa audit dari KAP Big 4 atau sebesar 58,9\%. Selain itu terdapat 76 sampel perusahaan yang menggunakan jasa audit dari KAP Big 4 atau

sampel perusahaan yang menjadi klien auditor spesialis industri atau sama dengan $34,1 \%$.

perusahaan yang dimiliki. Entitas anak perusahaan dalam penelitian ini menunjukkan nilai minimum 0 dan nilai maksimum 110 . Ratarata entitas anak perusahaan sebesar 9,6000 dengan deviasi standar 18,76462.

sama dengan $41,1 \%$. Hasil tersebut menunjukkan sampel perusahaan yang menggunakan jasa audit dari KAP Big 4 lebih sedikit dibandingkan sampel perusahaan yang menggunakan jasa audit dari KAP non-Big 4.

Tabel 5

Statistik Distribusi Frekuensi Kepemilikan Keluarga

\begin{tabular}{lll}
\hline & Frequency & Percent \\
\hline Non Keluarga (0) & 67 & 36,2 \\
Keluarga (1) & 118 & 63,8 \\
Total & 185 & 100 \\
\hline
\end{tabular}

Sumber : Data sekunder yang diolah, 2019

perusahaan yang tidak dimiliki oleh keluarga. Berdasarkan tabel 5 dapat diketahui terdapat 67 Selain itu terdapat 118 atau 63,8\% merupakan sampel perusahaan atau $36,2 \%$ merupakan perusahaan yang dimiliki oleh keluarga.

Tabel 6

Statistik Distribusi Frekuensi Kerugian

\begin{tabular}{lll}
\hline & Frequency & Percent \\
\hline Keuntungan (0) & 147 & 79,5 \\
Kerugian (1) & 38 & 20,5 \\
Total & 185 & 100 \\
\hline
\end{tabular}

Sumber : Data sekunder yang diolah, 2019 
Berdasarkan tabel 6 diperoleh informasi terdapat 147 sampel perusahaan atau $79,5 \%$ yang melaporkan adanya keuntungan selama periode pelaporan. Selain itu, terdapat 38 sampel

Tabel 7

Statistik Distribusi Frekuensi Tipe Industri

\begin{tabular}{lll}
\hline & Frequency & Percent \\
\hline Low Profile (0) & 63 & 34,1 \\
High Profile (1) & 122 & 65,9 \\
Total & 185 & 100 \\
\hline
\end{tabular}

Sumber : Data sekunder yang diolah, 2019

Berdasarkan tabel 7 diperoleh informasi terdapat 63 sampel perusahaan atau $34,1 \%$ yang merupakan perusahaan dengan low profile

industry. Selain itu, terdapat 122 sampel perusahaan atau $65,9 \%$ yang merupakan perusahaan dengan high profile industry. perusahaan atau $20,5 \%$ yang melaporkan adanya kerugian selama periode pelaporan.

\section{Diskusi Hasil Penelitian}

Tabel 8

Uji statistik $\mathbf{t}$

\begin{tabular}{|c|c|c|c|c|}
\hline Model & & B & $\mathrm{T}$ & Sig \\
\hline \multirow[t]{10}{*}{1} & (Constant) & 143,111 & 8,875 & ,000 \\
\hline & $\begin{array}{l}\text { Spesialisasi } \\
\text { Auditor }\end{array}$ & $-8,669$ & $-4,770$ & ,000 \\
\hline & Reputasi Auditor & 3,007 & 1,552 & ,123 \\
\hline & Audit Tenure & $-2,156$ & $-2,366$ & ,019 \\
\hline & Ukuran Perusahaan & $-2,064$ & $-3,517$ & 001 \\
\hline & Leverage & ,380 & ,607 &, 545 \\
\hline & Entitas Anak &, 016 &, 342 & ,733 \\
\hline & Keluarga & $-1,319$ &,- 844 & ,400 \\
\hline & Kerugian & 2,295 & 1,278 & ,203 \\
\hline & Industuri & $-2,513$ & $-1,595$ & ,113 \\
\hline
\end{tabular}

*Tingkat singnifikansi $<5 \%$

Sumber: Data sekunder yang diolah, 2019

\section{Pengaruh Spesialisasi Industri Auditor terhadap Audit Report Lag}

Berdasarkan interpretasi hasil penelitian, hipotesis pertama yang menyatakan spesialisasi industri auditor berpengaruh negatif terhadap audit report lag, menunjukkan nilai beta sebesar 8,669 dengan signifikansi sebesar 0,000. Oleh karena signifikansi dibawah $0,05 \%$ maka dapat disimpulkan hipotesis didukung.

Hasil penelitian ini sejalan dengan penelitian Rusmin dan Evans (2017) yang menyatakan 
Exchange dari tahun 2014-2018. Penelitian Habib dan Bhuiyan menemukan bukti bahwa audit report lag lebih pendek ketika perusahaan diaudit oleh spesialisasi industri auditor.

\section{Pengaruh Reputasi Auditor terhadap Audit Report Lag}

Berdasarkan interpretasi hasil penelitian, hipotesis kedua yang menyatakan reputasi auditor berpengaruh negatif terhadap audit report lag, menunjukkan nilai beta sebesar 3.007 dengan signifikansi sebesar 0,123 . Nilai signifikansi tersebut lebih besar dari 0,05 maka dapat dikatakan bahwa hipotesis tidak didukung.

Hal tersebut sejalan dengan penelitian Apadore dan Noor (2013) yang gagal menemukan bukti yang mendukung hubungan negatif antara perusahaan audit Big 4 dengan audit report lag. Penelitian Afify (2009) juga menemukan hal yang sama yaitu tidak ditemukan dukungan untuk hubungan yang signifikan antara auditor Big 4 dengan audit report lag.

Menurut Priyanti (2018) besar kecilnya sebuah Kantor Akuntan Publik atau berafiliasinya Kantor Akuntan Publik dengan Big 4 tidak dapat menjadi tolak ukur dari kualitas audit. Pada teori keagenan, salah satu biaya agensi adalah biaya pemantauan. Salah satu contoh dari biaya pemantauan adalah biaya audit eksternal. Besar kecilnya biaya audit eksternal nantinya ditentukan dari kemampuan perusahaan untuk mengeluarkan biaya tersebut. Biaya agensi yang dikeluarkan perusahaan untuk menyewa jasa audit sebagai bentuk penyelesaian masalah antara prinsipal dan agen ini dapat menimbulkan ketergantungan KAP pada klien, karena KAP akan berusaha memenuhi harapan yang diinginkan klien. Saat klien merasa puas dengan kinerja dari pihak KAP, maka mereka memiliki kecenderungan untuk tetap bertahan dengan KAP yang sama. Sehingga independensi dan objektifitas dari auditor akan menurun yang berdampak pada kualitas audit yang dihasilkan oleh auditor.

Menurut Aryandra dan Mauliza (2018) di Indonesia, baik KAP Big 4 maupun KAP non Big 4, tidak mempengaruhi jangka waktu penyelesaian pelaksanaan audit karena ketatnya persaingan membuat setiap KAP selalu berupaya menunjukkan profesionalisme yang tinggi. Dengan demikian, reputasi auditor tidak didasarkan pada nama besar KAP tersebut, namun juga pada kualitas audit yang dihasilkan.

\section{Pengaruh Audit Tenure terhadap Audit Report Lag}

Berdasarkan interpretasi hasil penelitian, hipotesis ketiga yang menyatakan audit tenure berpengaruh negatif terhadap audit report lag menunjukkan nilai beta sebesar -2.156 dengan signifikansi sebesar 0,019 . Oleh karena nilai signifikansi dibawah 0,05 maka dapat disimpulkan hipotesis didukung.

Hasil penelitian ini konsisten dengan hasil penelitian Dao dan Pham (2014) yang menyatakan audit tenure yang singkat menyebabkan audit report lag yang lebih panjang. Audit tenure berpengaruh terhadap pemahaman auditor atas perusahaan klien, auditor tersebut akan sulit memahami perusahaan klien pada awal-awal masa perikatan audit.

\section{SIMPULAN}

Hipotesis pertama yang menyatakan spesialisasi industri auditor berpengaruh negatif terhadap audit report lag didukung oleh hasil uji regresi. Hal ini berarti spesialisai indutri auditor akan mempersingkat audit report lag. Hipotesis kedua yang menyatakan reputasi auditor berpengaruh negatif terhadap audit report lag tidak didukung oleh hasil uji regresi. Hal ini mengindikasikan auditor Big 4 tidak memiliki pengaruh terhadap lamanya waktu penyelesaian audit. Hipotesis ketiga yang menyatakan audit tenure berpengaruh negatif terhadap audit report lag didukung oleh hasil uji regresi. Hal ini berarti audit tenure yang pendek akan mengindikasikan audit report lag yang panjang.

Berdasarkan hasil pengujian hipotesis, terdapat batasan dalam penelitian ini. Pertama, terdapat kriteria dari sampel penelitian yang tidak dapat dipenuhi oleh perusahaan manufaktur di Indonesia sehingga membuat jumlah sampel menjadi terbatas yaitu 67 perusahaan dari 157 perusahaan. Kedua, sulitnya untuk mengamati spesialisasi industri 
auditor maka penelitian ini menggunakan metode Krishnan (2003) dalam mengukur variabel tersebut yang hanya didasarkan pada persentase dari total aset klien sehingga ukuran spesialisasi industri auditor yang digunakan dalam penelitian ini mungkin tidak dapat mencerminkan spesialisasi industri auditor yang sebenarnya.

Berdasarkan keterbatasan pada penelitian ini maka terdapat saran yang akan diberikan. Pertama, menambah cakupan data selain sektor industri manufaktur saja, misalnya dengan menambah sektor industri jasa untuk melihat spesialisasi industri auditor selain bidang manufaktur. Kedua, menggunakan beberapa proxy lain dalam pengukuran spesialisasi industri auditor misalnya berdasarkan pada perbandingan antara jumlah emiten yang diaudit oleh KAP yang sama dengan total jumlah emiten dalam satu industri atau berdasarkan biaya audit.

\section{DAFTAR PUSTAKA}

Adams, Michael B. 1994. "Agency Theory and the Internal Audit." Managerial Auditing Journal $9(8): 8-12$

Afify, H. A. E. 2009. Determinants of audit report lag Does implementing corporate governance have any impact? Empirical evidence from Egypt.

Alkhatib, K., \& Marji, Q. 2012. Audit reports timeliness : Empirical evidence from Jordan, Vol 62, pp1342-1349.

Anggraeni, D.M. 2011. Agency Theory Dalam Perspektif Islam.

Apadore, K., \& Noor, M. M. 2013. Determinants of Audit Report Lag and Corporate Governance in, 8(15), 151-163.

Arens, A. A., R. J. Elder, dan M. S. Beasley. 2012. Auditing and Assurance Services. 14th ed. USA: Pearson Prentice Hall.

Aryandra, R. A. dan Mauliza. 2018. Faktor-Faktor yang Mempengaruhi Audit Report Lag Perusahaan Sektor Property dan Real Estate yang Terdaftar di Bursa Efek Indonesia Periode 2012-2015.

Becker, C. L., DeFond, M. L., Jiambalvo, J., and Subramanyam, K. R. 1998. "The effect of audit quality on earnings management", Contemporary Accounting Research, Vol. 15 No. 1.

Caneghem, T. V. 2004. "The impact of audit quality on earnings rounding-up behaviour: Some UK evidence", European Accounting Review, Vol. 13 No. 4.

Carcello, J. V., and Nagy, A. L. 2004. "Client size, auditor specialization and fraudulent financial reporting", Managerial Auditing Journal, Vol. 19 No. 5.

Chan, P., Ezzamel, M., and Gwilliam, D. 1993b. "Determinants of audit fees for quoted UK companies", Journal of Business Finance and Accounting.

Dao, Mai dan Trung Pham. 2014. Audit Tenure, Auditor Specialization, and Audit Report Lag. Managerial and Auditing Journal. Vol. 29. No. 6. hlm. 490-512.

Deangelo, L. E. 1981. Auditor Size And Audit Quality, 3(May), 183-199.

Dopuch, N., and Simunic, D. A. 1982. The competition in auditing: An assessment. Fourth Symposium on Auditing Research. University of Illinois, Urbana, U.S.

Dwiyanti, R. 2010. Analisis FaktorFaktor yang Mempengaruhi Ketepatan Waktu Pelaporan Keuangan Pada Perusahaan Manufaktur yang Terdaftar di Bursa Efek Indonesia.

Dyer, J. C. dan Mchugh, A. 2014. The Timeliness of the Australian Annual Report times, 13(2), 204-219.

Francis, J. R., and Wilson, E. R. 1988. "Auditor changes: A joint test of theories relating to agency costs and auditor differentiation", The Accounting Review, Vol. 63 No. 4.

Francis, J. R., Maydew, E. L., and Sparks, H. C. 1999. "The role of big 6 auditors in the credible 
reporting of accruals", Auditing: A Journal of Practice \& Theory, Vol. 18 No. 2.

Ghozali,I. 2016. Aplikasi Analisis Multivariete.Semarang:Badan Penerbit Undip.

Ghozali, I. dan A. Chariri. 2014. Teori Akuntansi.Semarang: Badan Penerbit Undip.

Gilling, D. M. 1977. "Timeliness in corporate reporting: Some further comment", Accounting and Business Research, Vol. 8 No. 29.

Gul, F. A., Fung, S. Y. K., and Jaggi, B. 2009. "Earnings quality: Some evidence on the role of auditor tenure and auditors' industry expertise", Journal of Accounting and Economics, Vol. 47 No. 3

Habib, Ahsan and Md Borhan Uddin Bhuiyan. 2011. Audit Firm Industry Specialization and the Audit Report Lag. Journal of International Accounting, Auditing and Taxation 20(1):3244. Retrieved

Hassan, Y. M. 2016. "Determinants of audit report lag: Evidence from Palestine", Journal of Accounting in Emerging Economies, Vol. 6 No. 1.

Jensen, M. C., \& Meckling, W. H. 1976. Theory of the Firm: Managerial Behavior, Agency Costs and Ownership Structure Theory of the Firm : Managerial Behavior, Agency Costs and Ownership Structure.

Krishnan, G. V. 2003. Does Big 6 Auditor Industry Expertise, (1997), 1-16.

Kurniasih, Margi And Abdul Rohman. 2014. "Pengaruh Fee Audit, Audit Tenure, dan Rotasi Audit Terhadap Kualitas Audit." 3:110.

Lee, H.-Y., Mande, V. and Son, M. 2009, "Do lengthy auditor tenure and the provision of non-audit services by the external auditor reduce audit report lags?", International Journal of Auditing, Vol. 13 No. 2.
Leventis, S., Weetman, P., and Caramis, C. 2005 "Determinants of audit report lag: Some evidence from the Athens Stock Exchange", International Journal of Auditing, Vol. 9 No. 1.

Michael, C. J., dan Rohman, A. 2017. Pengaruh Audit Tenure Dan Ukuran Kap Terhadap Audit Report Lag Dengan Spesialisasi Industri Auditor Sebagai Variabel Moderasi (Studi Empiris pada Perusahaan Manufaktur yang Terdaftar di Bursa Efek Indonesia tahun 2013-2015 ), 6(2014), 1-12.

O'Reilly, D. M., and Reisch, J. T. 2002. "Industry specialization by audit firms: What does academic research tell us?", Ohio CPA Journal, Vol. 61 No. 3

Otoritas Jasa Keuangan Republik Indonesia. 2016. Peraturan Otoritas Jasa Keuangan Republik Indonesia Nomor 29/POJK.04/2016 Tentang Laporan Tahunan Emiten Atau Perusahaan Publik. 1-29. Retrieved (www.ojk.go.id)

Palmrose, Z. V. 1986a. "Audit fees and auditor size: Further evidence", Journal of Accounting Research, Vol. Spring., pp. 97-110.

Palmrose, Z. V. 1986b. "The effect of nonaudit services on the pricing of audit services: Further evidence", Journal of Accounting Research, Vol. 24 No. 2, pp. 405-411.

Priyanti, D.F. 2018. "Pengaruh Audit Tenure, Rotasi Audit, Ukuran Kap, Dan Ukuran Perusahaan Klien Terhadap Kualitas Audit".

Putri, Alvyra Nesia Indah and Indira Januarti. 2014. "Faktor - Faktor Yang Berpengaruh Terhadap Audit Report Lag Pada Perusahaan Manufaktur Yang Terdaftar Di Bursa Efek Indonesia Periode Tahun 20082012." Diponegoro Journal of Accounting 3(2):64-73.

Rahmina, L.Y., dan Agoes, S. 2014. " Influence of auditor independence, audit tenure, and audit fee on audit quality of members of capital market accountant forum in Indonesia".

Rusmin, R., and Evans, J. 2017. Audit Quality and Audit Report Lag: Case of Indonesian Listed 
Dyah P. A. \& Adi F. R. / INDICATORS Journal of Economics and Business Vol 1 (2) (2019)

Companies. Asian Review of Accounting 25(2):191-210.

Sekaran, U. dan R. Bougie. 2017. Metode Penelitian untuk Bisnis. Penerbit Salemba Empat.

Solomon, I., Shields, M. D., \& Whittington, O. R. 1999. What Do Industry-Specialist Auditors Know?, 37(1), 191-208.

Valentino, Vincent. 2017. Pengaruh Struktur Kepemilikan Keluarga Dan Kinerja Perusahaan Pada Sektor Pertambangan. 613-24.

Watts, R. L., and Zimmerman, J. L. 1986. Positive accounting theory, ed., Prentice-Hall, Inc.Englewood Cliffs, U.S.

William, D. D., and Dirsmith, M. W. 1988. "The effect of audit technology on audit efficiency: Auditing and the timeliness of client earnings announcements", Accounting, Organizations and Society, Vol. 13 No. 5.

www.idx.co.id 